Jurnal MAKSIPRENEUR, Vol. II, No. 1, Hal 20-39

\title{
KONTRIBUSI ILMU MANAJEMEN DALAM PENGEMBANGAN CUSTOMER RELATIONSHIP MANAGEMENT (CRM)
}

\section{Ambar Lukitaningsih}

Fakultas Ekonomi Universitas Sarjanawiyata Tamansiswa

\begin{abstract}
Often found, that not all companies or businesses offering a product that they sell to realize the importance of a service to consumers. This could happen due to the many aspects of customer satisfaction, or products sold is a superior product or a great demand by consumers, so companies do not have anxiety or fear of abandonment by consumers. This paper attempts to reveal how management science has contributed to the marketing management in this system of CRM (Customer Relationship Management), which can be used by businesses to determine how these measures or ways to serve consumers, so that consumers feel satisfied, even become loyal customers and this will positively impact the company's survival. CRM (Customer Relationship Management) which is a customer relationship management company is required to conduct a business or a strategy to serve customers well. CRM role here is not limited to customer satisfaction, but even further customers can continue to purchase products and or services that companies offer, so that with the implementation of CRM, the company can serve customers well and maintain customer loyalty. With the CRM is an evidence that the effect of the development of management science now filed under social sciences is very strong, which was initially characterized by the approach of a strong math and engineering. Until now, the influence of the more powerful approach, although the contribution of other social sciences also increasing. The condition makes multisources management as a hybrid science becomes stronger and attracts many people to learn and even more so of great benefit. The tendency of the environment to be hyper-competitive economy, the role of science greater getting out of a variety of problems or crises.
\end{abstract}

Key Words: Relationship Management, Multi-source, Hybrid Science

\section{Pendahuluan}

Perkembangan manajemen sebagai bidang ilmu pengetahuan telah melibatkan banyak kalangan dengan berbagai upaya namun pada 
prakteknya manajemen seusia dengan peradaban manusia. Kontributor pengembangan manajemen sebagai ilmu pengetahuan datang dari praktisi (eksekutif dan insinyur) yang mentransformasi pengalaman produksinya ke dalam berbagai bentuk tulisan. Kontributor lainnya datang dari para professor di sekolah bisnis dan teknik yang tengah berusaha memenuhi persyaratan kependidikan dari profesi yang sedang berkembang ini (emerging profession). Kontributor diluar kedua bidang di atas berasal dari bidang studi sosiologi, psikologi, ekonomi, matematika, akuntansi dan statistika (Albers, 1969). Hal ini menjadikan gambaran bahwa manajemen bukanlah ilmu yang berdiri sendiri tapi sebagai suatu pengetahuan hibrida (hybrid science)

Perkembangan padabidangilmu sosial (psikologi, sosiologi, antropologi, ekonomi, politik, manajemen, akuntasi, sastra dan bahasa, dan ilmu budaya lainnya) tidak begitu kentara percepatannya dalam menyeimbangkan diri dengan perubahan akibat temuan teknologi yang ada. Namun disadari atau tidak, ranah kehidupan sosial keseharian sangat dipengaruhi oleh kemajuan teknologi. Jadi perkembangan ilmu sosial terkesan harus selalu melakukan penyesuaian diri dengan perkembangan teknologi. Berkaitan dengan perkembangan teknologi pada ilmu manajemen dalam hal ini adalah manjemen pemasaran yang membahas tentang Manajemen Hubungan Pelanggan (Customer Relationship Management) disingkat CRM adalah suatu jenis manajemen yang secara khusus membahas teori mengenai penanganan hubungan antara perusahaan dengan pelanggannya dengan tujuan meningkatkan nilai perusahaan di mata para pelanggannya. Pengertian lain mengatakan bahwa CRM adalah sebuah sistem informasi yang terintegrasi yang digunakan untuk merencanakan, menjadwalkan, dan mengendalikan aktivitas-aktivitas prapenjualan dan pascapenjualan dalam sebuah organisasi. CRM melingkupi semua aspek yang berhubungan dengan calon pelanggan dan pelanggan saat ini, termasuk di dalamnya adalah pusat panggilan (call centre), tenaga penjualan (sales force), pemasaran, dukungan teknis (technical support) dan layanan lapangan (field service). Belakangan ini konsep Customer Relationship Management ( CRM) menjadi primadona dalam kegiatan bisnis. Penyebabnya apalagi kalau bukan teknologi komunikasi dan informasi. Dengan teknologi ini setiap konsumen dapat dideteksi dan diamati satu persatu, bahkan dari hari ke hari, termasuk keluhan-keluhan (complaints) dengan beralih pada merek lain.

CRM diartikan sebagai satu kesatuan penjualan, pemasaran dan strategi pelayanan yang mencegah terjadinya aktivitas pekerjaan yang tidak terkoordinasi antar bagian dengan baik dan itu tergantung pada aksi - aksi perusahaan yang terkoordinasi (Kalakota, Ravi, Marcia, 2001). CRM berkonsentrasi pada apa yang dinilai oleh pelanggan, bukan pada apa yang perusahaan ingin jual. Pelanggan tidak menginginkan diperlakukan secara sama. Akan tetapi mereka ingin diperlakukan secara individual. Namun, 
pada dasarnya CRM merupakan suatu cara untuk menganalisis perilaku pelanggan yang dimiliki perusahaan, dan melalui hasil analisis tersebut, perusahaan dapat menentukan cara bagaimana agar dapat melayani para pelanggannya secara lebih personal, sehingga menimbulkan loyalitas pelanggan terhadap perusahaan.

Sasaran utama CRM bukan terletak pada kepuasan pelanggan, tetapi lebih mengarah pada loyalitas pelanggan. Maksudnya adalah agar pelanggan tidak hanya puas saat memakai produk perusahaan, melainkan meningkatkan loyalitas pelanggan pada perusahaan. (Strene, 2000). Seperti apa yang dikatakan (Kalakota,Ravi,Marcia,2001) sasaran dari kerangka kerja bisnis CRM adalah menggunakan hubungan yang ada untuk meningkatkan penghasilan, menggunakan informasi yang terintegrasi untuk pelayanan yang baik, memperkenalkan konsisten, proses dan prosedur chanel yang replicable.

Tujuan utama CRM sebenarnya adalah untuk menemukan Lifetime Value (LTV) dari pelanggan. Setelah LTV diperoleh, tujuan selanjutnya adalah bagaimana agar LTV masing-masing kelompok pelanggan dapat terus diperbesar dari tahun ke tahun. Setelah itu, tujuan berikutnya adalah bagaimana menggunakan profit yang didapat dari tujuan-tujuan tersebut untuk mendapatkan pelanggan baru dengan biaya yang relatif murah. Dengan demikian, tujuan jangka panjangnya adalah menghasilkan keuntungan terus-menerus dari dua kelompok pelanggan: pelanggan sekarang dan pelanggan baru.

Selain sisi teknologi, perusahaan dan para pemasarnya juga berlomba untuk memodifikasi strategi pemasarannya, mereka semakin mengerti bahwa pelanggan adalah nyawa atau kehidupan perusahaannya. Pelanggan, terutama pelanggan yang loyal, harus tetap dijaga agar tidak berpaling ke perusahaan lain. Dengan dukungan teknologi, dapat diciptakan strategi pemasaran yang mampu memberikan sentuhan pelayanan personal, yang memperlakukan pelanggan benar-benar seperti raja. Semua produk yang ditawarkan, proses penawaran sampai pada cara bertransaksi, disesuaikan dengan keinginan setiap individu pelanggan tersebut. Adapun manfaat dari penggunaan CRM adalah servis yang lebih cepat, mengurangi harga, memperbesar keuntungan, mempunyai rasa memiliki, meningkatkan koordinasi tim, tingkat kepuasan pelanggan menjadi lebih tinggi, meningkatkan loyalitas pelanggan. (Widjaja, 2000). Mendukung pendapat Fornell, Michael, Eygene dan Barbara (1996) mengatakan bahwa kepuasaan pelanggan keseluruhan ditentukan oleh faktor nilai yang dirasakan,kualitas yang dirasakan dan harapan pelanggan ke pelanggan keseluruhan yang mempunyai konsekuensi perilaku berupa komplain pelanggan dan kesetiaan pelanggan.

Tulisan ini mencoba untuk mengungkapkan bagaimana ilmu manajemen mempunyai kontribusi pada manajemen pemasaran dalam hal ini tentang 
sistem CRM (Customer Relationship Management), yang bisa digunakan oleh para pelaku bisnis untuk mengetahui bagaimana langkah-langkah atau cara-cara melayani konsumen, agar konsumen merasa puas, bahkan menjadi pelanggan setia dan ini akan berdampak positif bagi kelangsungan hidup perusahaan.

\section{PERKEMBANGAN ILMU MANAJEMEN}

Sebelum abad 20 sangat sedikit penerbitan yang berhubungan dengan manajemen. Secara terfragmentasi prinsip-prinsip manajemen dapat ditemui dari tulisan historical awal, para pemimpin agama, kalangan militer dan pemimpin politik. Sebagai contoh tulisan manajemen di bidang militer adalah The Art of War oleh ahli strategi perang dari Cina: Sun Tzu Wu tahun 500 SM. Berbagai tulisan dari mulai akhir abad 18 sampai dengan awal abad 20 oleh Robert Owen (1771-1858), Charles Babbage (1792-1871), Capt. Henry Metcalfe (1847-1917), Henry R.Towne (1844-1924), Frederick W. Taylor (1856-1915), Hewnry L. Gantt (1861-1919), Russell Robb (1864-1927), Harrington Emerson (1853-1931), Alexander H. Church (1866-1936), Leon P. Alford (1877-1942), Henri Fayol (1841-1925), Frank B. Gilberth (1868-1924), Oliver Sheldon (1894-1951), Mary P. Follett (1868-1933), Harry A. Hopf (1882-1949), George E. Mayo (1880- 1949), dan Max Weber (1949). Tulisantulisan mereka menjadi literatur klasik dalam ilmu manajemen (Merrill, 1960).

Manajemen sebelumnya dipraktekkan dengan bukti adanya Great Wall di Cina, Taman Gantung di Babilonia, Piramida di Mesir, Candi Borobudur di Jawa Tengah, dan Tajmahal di India. Revolusi industri di Inggris dan Amerika menjadikan tonggak sejarah bagi pengembangan ilmu manajemen modern, temuan revolusioner pada saat itu adalah mesin uap oleh James Watt. Metoda manajerial mulai digunakan dengan ditunjukkannya proses assembling dengan daftar pekerjaan detail baik untuk perorangan serta kelompok yang terstandarisir dan komponen mesin. Juga penggunaan forecast untuk perencanaan produksi dan elaborasi biaya yang dikeluarkan dalam proses produksi. Setelah revolusi industri system produksi memberikan ciri yang dominan dalam manajemen. Organisasi pabrik menjadikan pembedaan yang nyata antara fungsi manajemen dan non manajemen serta manajer dan pekerja membuat semakin nyata dominasi dari kapitalisme dalam perekonomian. Kemudian muncul kelas manajerial, dominasi para pemilik modal bergeser ke dominasi para manajer hal ini merupakan respon dari keterbatasan masa kepemilikan oleh individu dialihkan pada korporasi. Masa ini disebut oleh Drucker (1954) sebagai revolusi manajerial atau manajerialisme. Tanggunjawab manajer mengambil alih tanggungjawab pemilik modal, istilah hubungan pemodal dan buruh diganti dengan istilah manajer dan buruh. 
Fenomena yang menjadi reaksi berkembangnya industri dengan skala besar adalah munculnya serikat pekerja di awal abad 19. Filosofi serikat pekerja adalah peningkatan kesejahteraan pekerja hanya dapat dicapai dengan melalui peningkatan posisi tawar kolektif (collective bargaining) atas upah, jam kerja dan kondisi kerja. Collective bargaining biasanya berwujud dalam bentuk negosiasi kontrak antara manajemen dan serikat pekerja, manajemen membawa kepentingan pemilik modal dan serikat pekerja membawa kepentingan para pekerja.

Revolusi industri tahap dua berlangsung setelah Perang Dunia ke II dengan dibangunnya computer untuk pertama kali oleh Vannevar Bush dari MIT tahun 1930. Sejak 1950-an komputer dimanfaatkan dalam kegiatan bisnis dan memberikan dampak pada praktek manajemen. Dampak yang paling terasa adalah keefisienan dan keefektifan sebagai hasil dari pemrosesan informasi. Komputer sebagai teknologi informasi menjadikan sekarang situasi serba cepat berubah dengan terdorongnya siklus produk yang singkat.

\section{ILMU MANAJEMEN DAN LINGKUPNYA}

Manajemen adalah cara untuk mencapai tujuan melalui orang lain. Taylor (1915) dalam bukunya The Principles of Scienctific Management mengemukakan bahwa perencanaan merupakan postulate yang penting dalam manajemen ilmiah. Perencanaan yang sebelumnya dilakukan oleh pekerja, dalamsistem yangbaru(manajemensaintifik)pekerjaan perencanaan dilakukan oleh manajemen dengan mengikuti prinsip-prinsip ilmiah. Pada kenyataannya hasil yang didapat produktifitas meningkat sampai dengan tiga kali lipat dari sebelum menggunakan sistem baru (Albers, 1969). Konsep proses manajemen pertama kali diajukan oleh Henry Fayol (1949), hal mana praktek manajemen didukung fungsi manajerial yang terdiri atas: Planning, organizing, command, coordination dan control (PO3C). Sebelumnya oleh Gulick (1939) disebut sebagai planning, organizing, staffing, directing, coordinating, reporting dan budgeting (POSDCORB). Urwick (1941) menyebutkan fungsi manajemen adalah forecasting, leadership, delegating, dan investigating. Pada tahun 1937 dalam bukunya The Theory of Social and Economic Organization, Max Weber mengungkapkan model struktur birokrasi suatu organisasi, dimana organisasi hendaknya memiliki hirarki dan pembagian tugas yang jelas definsinya. Organisasi bisnis atau korporat yang pertama kali dikenal berhasil menjalankan prinsip manajemen ilmiah gaya Taylor adalah General Motor Corporation (GMC) di Detroit, Michigan, USA, di bawah kepemimpinan Alfred P. Sloan pada tahun 1920. Setelah itu banyak korporasi besar di Amerika mengikuti jejak GMC. Aspek lain dalam ilmu manajemen adalah perkembangan teori organisasi dengan kontributor awal dalam teori ini adalah Russell Robb dari Harvard University. Robb (1910) menyarankan organisasi bisnis untuk dibagi secara 
fungsional menjadi produksi, pemasaran, personalia, dan keuangan. Dalam literatur manajemen strategi aspek organisasi secara fungsional merupakan merupakan faktor yang menjadikan organisasi secara internal memiliki kekuatan (strengths) atau kelemahan (weaknesses).

\section{PERKEMBANGAN MANAJEMEN PEMASARAN}

Jika dikatakan bahwa marketing adalah ilmu yang dinamis, itu memang benar adanya, sejarah teori dan konsep marketing selalu mengikuti perubahan struktur sosial dan ekonomi masyarakat. Kemunculan ide-ide baru yang memperkaya ilmu marketing terus berkembang seiring revolusi besar peradaban manusia. Mungkin masih banyak yang belum tahu bahwa peradaban bisnis modern berkembang sejak adanya revolusi industri di tahun 1900. Revolusiinibenar-benarmengubahtatanan strukturdan perilaku masyarakat pada saat itu. Bisnis yang tadinya berciri merkantilis (berdagang) kemudian berubah menjadi kapitalis. Kekuatan modal dipergunakan untuk membangun pabrik dan organisasi perusahaan,memproduksi barang, dan memperdagangkannya.

Pada proses ini muncullah pandangan-pandangan baru tentang bagaimana perilaku pasar terjadi dan bagaimana sebuah lembaga menjalankan kegiatan operasional untuk memenuhi kebutuhan pasar. Hal-hal inilah yang kemudian melatarbelakangi munculnya ilmu praktik manajemen bisnis, termasuk marketing. Boleh jadi, ilmu marketing ketika itu memang menjadi jawaban atas berbagai pertanyaan yang tidak bisa diakomodasi oleh ilmu ekonomi yang telah berkembang terlebih dahulu. Marketing awalnya tak lebih dari aktivitas bisnis yang sederhana. Para ekonom pun hanya memasukkannya sebagai salah satu bentuk aktivitas ekonomi.

Namun, pendekatan yang lebih berciri sosiologis kemudian menunjukkan adanya pengembangan dari institusi (lembaga) yang disebut sebagai "market" dalam bahasa ekonomi. Pendekatan sosiologis melihat institusi market bisa dilihat sebagai institusi sosial dibandingkan ekonomi. Artinya, di market bukan hanya tempat bertemunya supply dan demand. Market adalah tempat bertemunya penjual dan pembeli. Market merupakan sebuah sistem sosial di mana kebutuhan setiap pihak akan materi tertentu akan bertemu.

Pada waktu itu, konsumsi dianggap sebagai akhir dari kegiatan produksi di dunia ekonomi. Padahal perilaku konsumsi sendiri sebenarnya merupakan ilmu yang bisa dieksplorasi lebih dalam. Demikian halnya dengan istilah "value". Ilmu ekonomi meletakkan value berhubungan dengan penambahan input dari faktor-faktor produksi. Padahal di dunia bisnis, value juga mencakup sesuatu yang intangible seperti pelayanan. Pendekatan marketing juga mempertanyakan apakah market dipengaruhi 
hanya oleh purchasing power (daya beli) masyarakat? Lebih jauh dari itu, para praktisi bisnis melihat bahwa market bukan sekadar dipengaruhi oleh daya beli, tetapi juga keinginan membeli yang dipengaruhi oleh iklan dan tenaga penjual. Advertising muncul lebih dulu, kelas pertama dari pelajaran marketing diberikan oleh ED Jones pada tahun 1902 di University of Michigan dan kemudian oleh Simon Litman di University of California pada tahun yang sama. Saat itu, pemikiran marketing masih berfokus pada masalah distribusi. Ini sesuai dengan ciri industri tahap awal yang berfokus pada distribusi massal. Namun, pengembangan pemikiran awal teori marketing justru banyak bermunculan dari universitas seperti Wisconsin, Harvard, Ohio State, University of Illinois dan Northwestern University.

Sebenarnya, walaupun belum dimasukkan dalam disiplin ilmu marketing, pemikiran tentang dunia iklan (advertising) sudah lebih dulu ada. Buku History of Advertising sudah muncul pada tahun 1875. Demikian pula halnya dengan selling sudah mendahului pengembangan ilmu marketing itu sendiri. Selling awalnya hanya sekedar sebuah seni menjual, tetapi kemudian dijadikan sebuah formula untuk dipelajari dan dianalisis.

Mulanya pendekatan marketing memang menyangkut tiga elemen: advertising, selling dan distribusi. Namun, banyak pemikiran yang kemudian menambahkan elemen-elemen dalam marketing. Seperti Ralph Butler dan Arch Shaw, dua ahli ini menambahkan elemen lain dalam marketing, yakni: komoditas, institusi, dan fungsional. Artinya marketing menyangkut pula soal produk, organisasi pemasaran dan juga proses serta kegiatan.

Untuk elemen distribusi, berkembang pula pemikiran baru yang disebut retailing sejak tahun 1914. Nystrom pada waktu itu menulis literatur ritel bukan saja dari sisi proses distribusi, tapi juga manajemen ritel. Dengan banyaknya tambahan elemen-elemen baru dalam marketing, maka ilmu marketing kemudian masuk ke dalam tahapan integrasi. Pada tahap ini para pemikir dan ilmuwan mencoba menggabungkan berbagai ilmu, literatur serta elemen yang berdiri sendiri menjadi sebuah konsep yang terintegrasi. Buku Principles of Marketing pertama muncul lewat tangan Paul Ivey pada tahun 1920-an. Buku ini menggabungkan semua teori dan pemikiran yang berkembang di dunia marketing. Tetapi, yang lebih mengemuka kemudian adalah buku Principles of Marketing karangan Maynard, Weidler dan Beckman. Berbeda dibandingkan Ivey yang berfokus pada sisi pengusaha, buku ini lebih berfokus pada sudut pandang konsumen.

Teori marketing belum berakhir dengan dimunculkannya buku-buku tadi. Pada dekade-dekade berikutnya masuklah berbagai unsur yang memperkaya marketing. Ilmu-ilmu psikologi dan sosial mulai masuk. Demikian pula dengan konsep seperti segmentasi baru hadir belakangan setelah muncul konsep-konsep lain seperti marketing mix (4P). 
Elemen-elemen dalam marketing sendiri mengalami perkembangan. Sebagai contoh, ilmu advertising semakin berkembang dengan masuknya media-media baru seperti televisi yang mulai populer pada tahun 1960-an. Pada tahun 1960-an dan 1970-an ilmu marketing justru memecahkan diri ke dalam berbagai diferensiasi (kekhususan) seperti international marketing, social marketing, marketing for non-profit organization dan lain-lain. Konsep social responsibility juga menjadi salah satu konsep yang sudah mulai terbentuk pada tahun 1970.

Kejayaan Kotler sebagai "Bapak Marketing" sendiri dimulai pada periode 1970-an. Peran Kotler dalam dunia marketing memang pada kemampuannya menerjemahkan konsep marketing ke terminologi yang mudah dipahami oleh banyak orang. Kotler-lah yang mengubah konsep marketing ke bentuk-bentuk aplikasi tertentu seperti marketing untuk health service, public service, educational service, politik, dan lain-lain.

Tahun 1967, misalnya, Kotler sudah memperkenalkan konsep manajemen marketing modern yang meliputi analisis marketing opportunities, mengorganisasikan aktivitas marketing, kegiatan perencanaan marketing serta kontrol. Buku-buku Kotler kemudian menginspirasi banyak para pengajar dan praktisi di dunia marketing seluruh dunia. Bahkan, tak ada kuliah marketing yang tak lepas dari karya-karya Kotler. Buku Principles of Marketing dan Marketing Management dari Kotler membentuk pemikiranpemikiran dasar dan fundamental yang mempengaruhi berbagai pemikiran baru lainnya di dunia marketing.

Pada dekade 1980-an, pemikiran baru di dunia marketing seperti positioning yang dipopulerkan oleh Jack Trout dan Al Ries serta brand equity yang dipopulerkan oleh David Aaker semakin menguat. Era kemajuan bisnis di banyak negara pada dekade tersebut menciptakan kompetisi bisnis yang semakin ketat. Karenanya, peran dari sebuah merek dan upaya untuk mendiferensiasikan diri juga mengemuka. Dekade 1980 dan 1990an adalah dekade menguatnya unsur service dan kepuasan pelanggan di dalam marketing. Konsep seperti Servqual, Service profit chain dan juga services marketing mulai bermunculan. Gelombang baru ketika dunia memasuki gelombang revolusi berikutnya, yakni revolusi teknologi informasi, maka pemikiran-pemikiran marketing baru pun bermunculan mengikuti gelombang revolusi tersebut. Salah satunya konsep experiential marketing. Dengan adanya teknologi informasi, internet dan multimedia membuat experiential marketing lebih bisa berkembang. Demikian pula di dunia service, peran IT membuat konsep CRM (Customer Relationship Management) juga ikut berkembang. Belum lagi jargon-jargon baru seperti buzz marketing, viral marketing dan lain-lain. Tentu saja, seiring dengan revolusi ini, maka marketing pun harus berubah dalam cara memandang kompetisi. Aliansi dan co-branding adalah cara memandang kompetisi baru, di mana kerja sama dengan segenap pihak, termasuk kompetitor bisa menjadi kunci kemenangan. 
Juga konsep "blue ocean" yang mendesak para marketer untuk menciptakan kompetisi yang baru daripada bersaing di pasar yang sudah semakin sesak. Revolusi baru juga berimbas pada perkembangan media periklanan. Semakin berkembang dan kompleksnya media untuk berpromosi membuat marketer semakin berhati-hati menginvestasikan dananya.

Oleh karena itu muncul pemikiran-pemikiran baru yang menggugah para marketing untuk menghitung return on investment dari aktivitas marketing yang dilakukannya. Marketing dihadapkan pada kenyataan bahwa kegiatan mereka harus mampu dijelaskan dengan bahasa-bahasa finansial. Marketing ROI, CLV (Customer Lifetime Value), dan lain-lain adalah pemikiran-pemikiran yang kemudian mulai muncul.

Dari berbagai pergolakan pemikiran marketing tadi bisa disimpulkan bahwa pemikiran marketing, mau tidak mau, harus terus berubah dan berkembang sesuai dengan perubahan struktural yang terjadi dalam tatanan sosial ekonomi masyarakat, bentuk dan tingkat kompetisi yang ada serta perkembangan teknologi. Setelah revolusi industri dan IT, dunia diramalkan akan masuk ke revolusi bioteknologi.

\section{RUANG LINGKUP CUSTOMER RELATIONSHIP MANAGEMENT (CRM)}

Dengan adanya internet, tembok penghalang yang membatasi pelaku bisnis baru untuk melakukan penetrasi pasar menjadi sangat kabur, kalau tidak bisa dikatakan tidak ada. Sekarang seorang pelaku bisnis baru bisa melakukan bisnisnya dengan rekanan dari luar kota, negara bahkan lintas benua (asumsi penulis: bisnis dilakukan dengan legal dan benar). Yang namanya 'indie' tidak asing lagi di dunia maya ini, jutawan-jutawan baru lahir karena adanya internet.

Di sisi lain, di pihak pelaku bisnis yang mapan dengan merek besar mereka, situasi di atas bisa jadi menguntungkan atau malah merugikan. Perbedaan teknologi sudah tidak penting lagi karena para pemain baru bisa mendapatkan teknologi yang sama itu dengan gampang. Jadi kalau perusahaan besar masih mengandalkan produknya (product focus) niscaya mereka bakal tersusul oleh pemain-pemain baru itu. Hal ini dikarenakan faktor pembeda produk pemain lama dan pemain baru tidak banyak lagi. Sebagai contoh: sudah pernah ditawari portabel VCD player bikinan negeri tirai bambu? Harga yang ditawarkan tidak bisa untuk membeli walkman merek negeri sakura yang berteknologi auto reverse dan super-duper bass. Tetapi, umur produknya tidak beda jauh jika dipakai sama hati-hatinya. Teknologi lasernya sama persis. Bahkan feature-nya tidak kalah dan garansinya bisa diminta. 
Karena hal inilah perusahaan-perusahaan besar (enterprise) mencoba mengganti arah bisnis mereka fokus ke pelanggan (customer focus). Fakta mengatakan bahwa biaya untuk mendapatkan pelanggan baru bisa 10 kali biaya untuk menjaga pelanggan yang sudah ada. Sementara itu pelanggan juga memiliki kecenderungan untuk tidak hanya 'transaksional', beli barang - dapat barang - selesai, tetapi ingin lebih, beli barang - memilih service - dapat barang dan service - beli lagi. Sehingga pelanggan menginginkan hubungan dua arah dengan perusahaan-perusahaan yang mampu memberikan pelayanan tambahan tanpa terasa 'mahal'.

Selain kecenderungan naiknya kompetisi global di atas dimana produk-produk yang ada sangat sulit dibedakan, kecenderungan lain yang melahirkan CRM adalah majunya teknologi manajemen data yang memungkinkan disimpannya jutaan data dalam satu sistem tunggal. Dua puluh tahun yang lalu, informasi tentang pelanggan akan disimpan dalam dua puluh sistem yang berbeda dan tidak ada teknologi yang mampu mengelola informasi kompleks tentang pelanggan. Data yang ada bisa dari telepon, email, faksimili, tulisan tangan staf sales dan marketing, kartu nama, dll.

CRM berawal sekitar tahun 1990-an sebagai langkah logis setelah ramerame Enterprise Resource Planning (ERP). Satu faktor lagi yang melahirkan CRM adalah penelitian marketing oleh PIMS yang menyimpulkan bahwa "pelanggan yang menggerutu tidak puas akan bercerita kepada sekitar 7-10 orang temannya sedangkan pelanggan yang puas akan merekomendasikan perusahaan bersangkutan ke 3-4 teman mereka.

\section{Definisi Customer Relationship Management ( CRM )}

Setelah era digital yang selalu menggunakan "e-" didepan semua kata seperti e-commerce, e-book, e- sales, e-mail, dst, Customer Relationship Management atau CRM merupakan akronim atau singkatan yang paling populer dikalangan orang- orang sales dan marketing. Kalau di-bahasa Indonesia-kan kira-kira adalah Manajemen Hubungan Pelanggan (MHP).

Telaah per katanya adalah sebagai berikut; Pelanggan atau customer, kata pertama, di kamus bahasa Inggris artinya adalah seseorang yang berulang kali atau teratur melakukan pembelian kepada seorang pedagang. Jadi pelanggan adalah orangnya (dalam definisi ini tidak disinggung tentang kepuasan, mahal-murahnya pembelian, dll). Hubungan atau relationship, kata kedua, adalah bentuk komunikasi dua arah antara pembeli dan penjual. Manajemen, kata terakhir, artinya pengelolaan (secara luas tanpa perlu menjabarkan detail bagaimana mengelola sesuatu). Jadi definisi di atas kalau digabungkan kira- kira menjadi pengelolaan hubungan dua arah antara suatu perusahaan dengan orang yang menjadi pelanggan di perusahaan tersebut. 
CRM diartikan sebagai satu kesatuan penjualan, pemasaran dan strategi pelayanan yang mencegah terjadinya aktivitas pekerjaan yang tidak terkoordinasi antar bagian dengan baik dan itu tergantung pada aksi - aksi perusahaan yang terkoordinasi (Kalakota, 2001). CRM berkonsentrasi pada apa yang dinilai oleh pelanggan, bukan pada apa yang perusahaan ingin jual. Pelanggan tidak menginginkan diperlakukan secara sama. Akan tetapi mereka ingin diperlakukan secara individual. Namun, pada dasarnya CRM merupakan suatu cara untuk menganalisis perilaku pelanggan yang dimiliki perusahaan, melalui hasil analisis tersebut, perusahaan dapat menentukan cara bagaimana agar dapat melayani para pelanggannya secara lebih personal, sehingga menimbulkan loyalitas pelanggan terhadap perusahaan. Sasaran utama CRM bukan terletak pada kepuasan pelanggan, tetapi lebih mengarah pada loyalitas pelanggan. Maksudnya adalah agar pelanggan tidak hanya puas saat memakai produk perusahaan, melainkan meningkatkan loyalitas pelanggan pada perusahaan. (Strene, 2000). berikut:

CRM dalam perkembangannya juga bisa didefinisikan sebagai

a. CRM adalah sebuah istilah industri TI untuk metodologi, strategi, perangkat lunak (software) dan atau aplikasi berbasis web lainnya yang mampu membantu sebuah perusahaan (enterprise, kalau besar ukurannya) untuk mengelola hubungannya dengan para pelanggan, atau

b. CRM adalah usaha sebuah perusahaan untuk berkonsentrasi menjaga pelanggan (supaya tidak lari ke pesaing) dengan mengumpulkan segala bentuk interaksi pelanggan baik itu lewat telepon, email, masukan di situs atau hasil pembicaraan dengan staf sales dan marketing, atau

c. CRM adalah sebuah strategi bisnis menyeluruh dari suatu perusahaan yang memungkinkan perusahaan tersebut secara efektif bisa mengelola hubungan dengan para pelanggan.

Para ahli marketing juga mengatakan bahwa tidak mudah mendefinisikan apa itu CRM. Ini dikarenakan luasnya cakupan CRM terhadap aktivitas sales dan marketing yang pada akhirnya menjadi bagian dari manajemen pengetahuan (knowledge management) dari perusahaan itu sendiri.

TI (Teknologi Informasi) merupakan bagian terpenting dari CRM karena tanpa kemampuan teknologi komputer yang handal untuk mengolah besarnya informasi yang berhasil dikumpulkan, CRM akan lumpuh dan tidak ada artinya.

Sasaran dari kerangka kerja bisnis CRM adalah menggunakan hubungan yang ada untuk meningkatkan penghasilan, menggunakan 
informasi yang terintegrasi untuk pelayanan yang baik, memperkenalkan konsisten, proses dan prosedur chanel yang replicable. (Kalakota, 2001)

\section{Tujuan Customer Relationship Management (CRM)}

Tujuan utama CRM sebenarnya adalah untuk menemukan Lifetime Value (LTV) dari pelanggan. Setelah LTV diperoleh, tujuan selanjutnya adalah bagaimana agar LTV masing-masing kelompok pelanggan dapat terus diperbesar dari tahun ke tahun. Setelah itu, tujuan berikutnya adalah bagaimana menggunakan profit yang didapat dari tujuan-tujuan tersebut untuk mendapatkan pelanggan baru dengan biaya yang relatif murah. Dengan demikian, tujuan jangka panjangnya adalah menghasilkan keuntungan terus-menerus dari dua kelompok pelanggan: pelanggan sekarang dan pelanggan baru.

Selain sisi teknologi, perusahaan dan para pemasarnya juga berlomba untuk memodifikasi strategi pemasarannya. Mereka semakin mengerti bahwa pelanggan adalah nyawa atau kehidupan perusahaannya. Pelanggan, terutama pelanggan yang loyal, harus tetap dijaga agar tidak berpaling ke perusahaan lain. Dengan dukungan teknologi, dapat diciptakan strategi pemasaran yang mampu memberikan sentuhan pelayanan personal, yang memperlakukan pelanggan benar-benar seperti raja.Semua produk yang ditawarkan, proses penawaran sampai pada cara bertransaksi, disesuaikan dengan keinginan setiap individu pelanggan tersebut. Hasil AMR Research melaporkan beberapa penyedia software CRM seperti Siebel Systems, Clarify (Nortel Networks), PeopleSoft dan Oracle sebagai pemimpin pasar. Juga beberapa perusahaan kecil kompetitif seperti SalesLogix, Onyx Software, Pivotal, E.piphany, Kana dan Silknet Software. Sementara itu perusahaan-perusahaan penyedia jasa profesional CRM sebagai pemimpin pasar misalnya Accenture, Art Technology Group, Cambridge Technology Partners, CSC, Deloitte Consulting, EDS, eLoyalty, Cap Gemini Ernst \& Young, IBM Global Services, KPMG Consulting dan PriceWaterhouseCoopers.

\section{Manfaat, Keuntungan dan Implementasi CRM}

Manfaat dari penggunaan CRM adalah servis yang lebih cepat, mengurangi harga, memperbesarkeuntungan, mempunyai rasa memiliki, meningkatkan koordinasi tim, tingkat kepuasan pelanggan menjadi lebih tinggi, meningkatkan loyalitas pelanggan.(Widjaja, 2000). Potensi manfaat bisnis dari manajemen hubungan pelanggan sangat banyak. Contohnya, CRM memungkinkan sebuah perusahaan untuk mengidentifikasi serta berfokus pada para pelanggan terbaik mereka, yaitu mereka yang paling menguntungkan bagi perusahaan, agar mereka dapat dipertahankan sebagi pelanggan seumur hidup untuk layanan yang lebih besar dan menguntungkan. Manajemen hubungan pelanggan memungkinkan penyesuaian dan personalisasi real-time atas berbagai produk dan jasa 
berdasarkan pada keinginan, kebutuhan, kebiasaan membeli serta siklus hidup para pelanggan. CRM juga dapat menelusuri saat ketika pelanggan menghubungi perusahaan, darimana pun titik hubungannya. Sistem CRM juga memungkinkan perusahaan untuk memberi pengalaman yang konsisten dan layanan serta dukungan superior bagi pelanggan, di semua titik kontak yang dipilih oleh pelanggan. Semua manfaat ini akan memberi nilai bisnis strategis bari perusahaan dan nilai pelanggan yang besar bagi para pelanggannya. (O'Brien, 2005)

\section{Keuntungan Penggunaan CRM}

CRM membantu perusahaan untuk mengembangkan produk baru berdasarkan pengetahuan yang lengkap tentang keinginan pelanggan, dinamika pasar dan pesaing dengan cara:

a. Menjaga pelanggan yang sudah ada - Menarik pelanggan baru

b. Cross Selling: menjual produk lain yang mungkin dibutuhkan pelanggan berdasarkan pembeliannya

c. Upgrading: menawarkan status pelanggan yang lebih tinggi (gold card vs. silver card)

d. Identifikasi kebiasaan pelanggan untuk menghindari penipuan

e. Mengurangi resiko operasional karena data pelanggan tersimpan dalam satu sistem

f. Respon yang lebih cepat ke pelanggan

g. Meningkatkan efisiensi karena otomasi proses

h. Meningkatkan kemampuan melihat dan mendapatkan peluang

\section{Implementasi CRM}

Customer relationship management adalah strategi tingkat korporasi, yang berfokus pada pembangunan dan pemeliharaan hubungan dengan pelanggan. Beberapa paket perangkat lunak telah tersedia dengan pendekatan yang berbeda-beda terhadap CRM. Bagaimanapun, CRM bukanlah teknologi itu sendiri, tapi ia adalah pendekatan holistik terhadap falsafah organisasi, yang menekankan hubungan yang erat dengan pelanggan. CRM mengurus filosofi organisasi pada semua tingkatan, termasuk kebijakan dan proses, customer service, pelatihan pegawai, pemasaran, dana manajemen sistem dan informasi. Sistem CRM mengintegrasikan pemasaran, penjualan, dan customer service dari ujung ke ujung

Untuk mengimplementasikan sebuah strategi CRM, diperlukan paling tidak 3 (tiga) faktor kunci yaitu (1) orang-orang yang profesional (kualifikasi memadai), (2) proses yang didesain dengan baik dan (3) teknologi yang memadai (leading-edge technology). Tenaga yang profesional tidak saja mengerti bagaimana menghadapi pelanggan tetapi juga mengerti cara menggunakan teknologi (untuk CRM). Apapun tanpa 
desain yang baik akan gagal, begitu juga CRM. Perusahaan pengguna CRM harus sudah mengetahui tujuan (business objectives) dan tuntutan bisnis (business requirements) yang diinginkan dari implementasi CRM ini.

Teknologi CRM paling tidak harus memiliki elemen-elemen berikut:

a. Aturan-aturan Bisnis : tergantung dari kompleksitas transaksi, aturan-aturan bisnis harus dibuat untuk memastikan bahwa transaksi dengan pelanggan dilakukan dengan efisien. Misalnya pelanggan dengan pembelian besar yang mendatangkan keuntungan besar harus dilayani oleh staf penjualan senior dan berpengalaman, dst.

b. Penggudangan Data (data warehousing) : konsolidasi dari informasi tentang pelanggan harus dilakukan dalam satu sistem terpadu. Hasil analisis harus mampu menampilkan petunjuk-petunjuk tertentu tentang pelanggan sehingga staf penjualan dan marketing mampu melakukan kampanye terfokus terhadap grup pelanggan tertentu. Nantinya gudang data ini juga harus mampu menaikkan volume penjualan dengan cross-selling atau up-selling.

c. Situs (web) : jelas CRM harus memiliki kemampuan swalayan. Hanya aplikasi berbasis

d. Situs (web based) yang bisa mendukung ini. Pelanggan bisa melakukan transaksi sendiri, tahu berapa yang harus dibayar, dsb.

e. Pelaporan (reporting) : teknologi CRM harus mampu menghasilkan laporan yang akurat dan komprehen, nantinya berguna untuk menganalisis kelakuan pelanggan, dll.

f. Meja Bantu (helpdesk) : teknologi yang mampu mengintegrasikan informasi pelanggan ke aplikasi meja bantu akan menunjukkan ke pelanggan seberapa serius sebuah enterprise menangani pelanggannya.

Banyak perusahaan menawarkan solusi-solusi CRM yang 'tinggal pakai' yang memiliki tingkat fungsionalitas yang beragam. Biasanya produk- produk ini sudah cukup memadai. Tetapi bukan itu yang membuat sukses implementasi CRM. Bisnis proses yang terintegrasi dan konsolidasi data yang sudah ada saat implementasi CRM yang bakal menjamin suksesnya CRM itu sendiri.

Perusahaan-perusahaan yang menerapkan CRM mendapatkan pengertian yang lebih baik tentang pelanggan mereka dan kebutuhan mereka. Dikombinasikan dengan penggudangan data, bank data dan meja bantu atau pusat panggilan (call center), CRM membantu perusahaan untuk mengumpulkan dan menganalisis informasi tentang sejarah pelanggan, apa-apa yang menjadi kesenangannya, apa saja keluhannya dan bahkan data lain untuk memperkirakan apa yang akan dibeli pelanggan di masa datang. 


\section{Strategi CRM dan Permasalahannya}

Tujuan dari strategi CRM adalah untuk membentuk interaksi antara perusahaan dan pelanggannya dengan cara memaksimalkan nilai hidup pelanggan untuk perusahaan. Hal ini juga mencerminkan filosofi bahwa tidak semua pelanggan diciptakan sama.

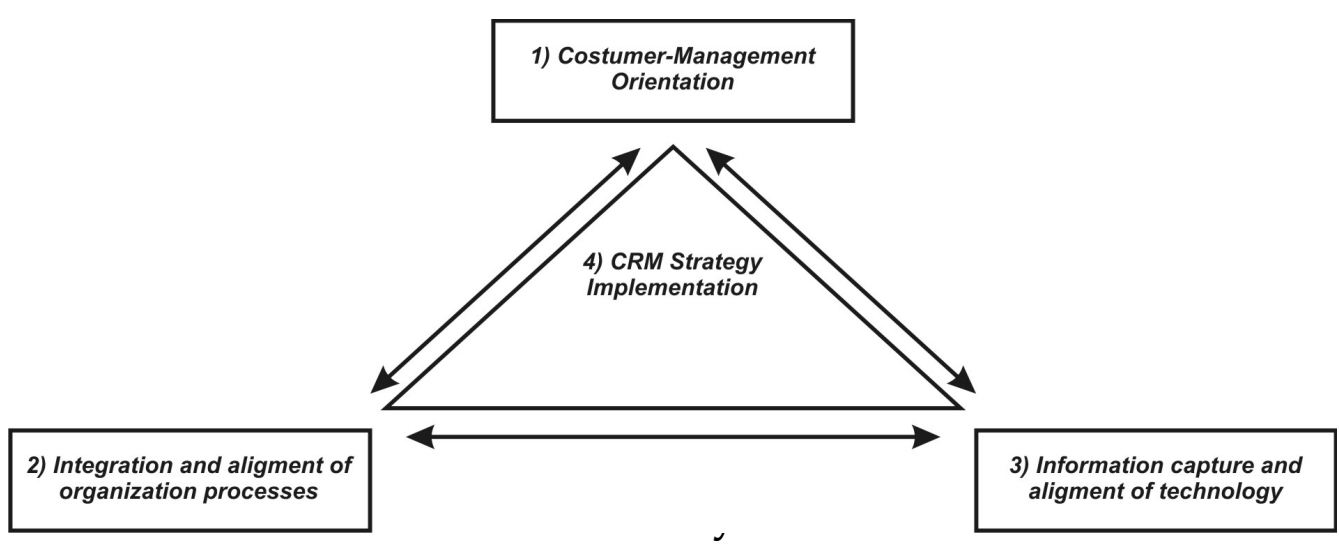

Penjelasan Gambar

Strategi CRM membutuhkan empat komponen :

1. Customer-management orientation

Customer-management orientation mencakup sekumpulan nilai-nilai perusahaan serta strategi dan aksinya dalam mengimplementasikan customer management principles

2. Integration and alignment of organizational processes

Integration and alignment of organizational processes dikelola dengan memahami nilai yang akan diberikan pada pelanggan yang sudah ditargetkan sesuai dengan prosesnya. Komponen ini dapat digunakan untuk menjelaskan dan merancang proses organisasinya

3. Information capture and alignment of technology

Information capture and alignment of technology dikarakteristikan oleh kemampuan dalam mentransfer data menjadi dalam bentuk informasi

4. CRM strategy implementation

Pengimplementasian CRM dalam proses dan aktivitas dibutuhkan untuk menyukseskan strategi CRM

Tahapan pokok CRM terdiri dari :

1. Analisis portofolio pelanggan akan menghasilkan pengelompokan 
pelanggan-pelanggan mana yang menguntungkan sehingga perlu mendapatkan perhatian yang lebih dan pelanggan mana yang kurang/ tidak menguntungkan. Untuk analisis portofolio ini diperlukan data atau informasi tentang pelanggan.

2. Customer intimacy, untuk memelihara kedekatan dengan pelanggan perusahaan harus mempunyai data warehousing yang baik sehingga melalui analisis data peruahaan dapat lebih mengenal pelanggan dengan lebih baik pula.

3. Dukungan dari jejaring (seperti: suppliers, owners, partners, employees) sangatlah diperlukan agar perusahaan mampu memberikan yang terbaik bagi pelanggan.

4. Dengan mengenal pelanggan secara lebih baik dan mengetahui kemampuan dirinya (termasuk dukungan jejaring), perusahaan dapat mengembangkan dan memberikan customer value yang lebih melalui pengembangan beberapa benefits bagi pelanggan.

5. Dengan memanajemeni daur hidup pelanggan secara lebih baik diharapkan customer life dapat diperpanjang dan biaya transaksi akan berkurang, sehingga perusahaan boleh berharap akan mendapatkan keuntungan yang besar.

Lima tahapan pokok CRM di atas dapat berjalan dengan optimal bila mendapatkan dukungan yang memadai dari lingkungannya seperti: kepemimpinan (pemimpin yang mempunyai komitmen terhadap CRM), kultur (berorientasi pada pelanggan), teknologi informasi dan data, manusia (manajemen dan karyawan memiliki pengetahuan dan keterampilan yang baik), serta sistem proses.

\section{Masalah Yang Dihadapi CRM}

Yang perlu dipahami adalah bahwa teknologi merupakan bagian terakhir untuk melengkapi seluruh proses CRM. Teknologi bukan segalanya dalam CRM, teknologi bisa dibawa belakangan dan teknologi siap pakai sudah tersedia.

Yang utama adalah persiapan proses bisnis, tujuan implementasi, sampai sedalam apa CRM mau digunakan, sejauh mana hubungan dengan pelanggan mau dibina, data atau sistem apa yang sudah dan sedang digunakan. Luangkan sedikit ekstra waktu untuk menjawab semua itu baru setelah itu memikirkan biaya, skala, servis yang dibutuhkan, penyedia jasa yang diperlukan, konsultan pendidik yang harus didatangkan dan solusi CRM macam apa yang vendor tawarkan. Masalah fatal dan besar yang mungkin terjadi, seperti aplikasi TI lainnya, adalah terbuangnya feature atau kelebihan-kelebihan yang ditawarkan TI secara percuma. Pelanggan tetap mengeluh, hubungan dengan pelanggan tetap transaksional, tidak ada peningkatan efisiensi, staf sales dan marketing masih saling menyembunyikan data, profit perusahaan yang stagnan. 


\section{PERAN ILMU MANAJEMEN DALAM PENGEMBANGAN CRM}

Dengan adanya ilmu manajemen yang mempunyai peran dalam bidang manajemen pemasaran dalam hal ini adalah manajemen hubungan pelanggan, akan membawa potensi manfaat bisnis yang sangat banyak. Contohnya, CRM memungkinkan sebuah perusahaan untuk mengidentifikasi serta berfokus pada para pelanggan terbaik mereka, yaitu mereka yang paling menguntungkan bagi perusahaan, agar mereka dapat dipertahankan sebagi pelanggan seumur hidup untuk layanan yang lebih besar dan menguntungkan. Manajemen hubungan pelanggan memungkinkan penyesuaian dan personalisasi real-time atas berbagai produkdanjasa berdasarkan pada keinginan, kebutuhan, kebiasaan membeli serta siklus hidup para pelanggan. CRM juga dapat menelusuri saat ketika pelanggan menghubungi perusahaan, darimana pun titik hubungannya. Sistem CRM juga memungkinkan perusahaan untuk memberi pengalaman yang konsisten dan layanan serta dukungan superior bagi pelanggan, di semua titik kontak yang dipilih oleh pelanggan. Semua manfaat ini akan memberi nilai bisnis strategis bagi perusahaan dan nilai pelanggan yang besar bagi para pelanggannya. (O'Brien, 2005)

Sering dijumpai, bahwa tidak semua perusahaan atau pelaku bisnis menawarkan suatu produk yang mereka jual menyadari akan pentingnya suatu pelayanan terhadap konsumen. Hal ini bisa terjadi akibat banyaknya aspek kepuasan konsumen, atau produk yang dijual merupakan produk unggulan atau banyak diminati oleh para konsumen, sehingga perusahaan tidak memiliki kecemasan atau kekhawatiran akan ditinggalkan oleh konsumen.

Dapat dibayangkan, seberapa besar keuntungan yang dilepaskan begitu saja jika perusahaan tidak mempedulikan kepuasan konsumen. CRM (Customer Relationship Management) merupakan suatu jenis manajemen yang secara khusus membahas teori mengenai penanganan hubungan antara perusahaan dengan pelanggannya dengan tujuan meningkatkan nilai perusahaan di mata para pelanggannya.

\section{PENUTUP}

Dari uraian di atas beberapa hal dapat disimpulkan bahwa paradigma perkembangan manajemen hubungan pelangan (CRM) dalam ranah Manajeman Pemasaran tidak terlepas dari perkembangan Ilmu Manajemen.

CRM (Customer Relationship Management) merupakan suatu jenis 
manajemen yang secara khusus membahas teori mengenai penanganan hubungan antara perusahaan dengan pelanggannya dengan tujuan meningkatkan nilai perusahaan di mata para pelanggannya. Tujuan utama dari CRM adalah untuk meningkatkan pertumbuhan jangka panjang dan profitabilitas perusahaan melalui pengertian yang lebih baik terhadap kebiasaan (behavior) pelanggan.

Fungsi CRM akan memudahkan perusahaan untuk mengetahui dan memahami lifetime value of customer dan memberikan layanan personal yang sempurna. Fokus utama yang paling penting di sini adalah bagaimana perusahaan bisa memelihara pelanggan khususnya dalam melakukan kegiatan pemasaran, segala usaha dilakukan untuk dapat meraih pelanggan sebanyak-banyaknya. Semakin banyaknya kondisi pasar yang terpecahpecah dan produk-produk baru yang timbul serta semakin beraneka ragam, peluang pelanggan semakin besar pula di dalam mendapatkan produk yang mereka inginkan serta sesuai dengan kebutuhan. Akan tetapi, saat ini bukan bagaimana menyampaikan produk perusahaan sampai ke tangan pelanggan, tetapi bagaimana cara perusahaan dapat menyediakan produk yang sesuai dengan keinginan dan kebutuhan pelanggan.

Agar program CRMberhasil, perludilakukan langkah yaitu menciptakan suatu strategi pelanggan. Dimulai dengan memahami pelanggan mana yang ingin dibangun relasinya dan mana yang bukan. Setiap pelanggan memiliki kebutuhan yang berbeda dan demikian pula mereka memiliki nilai yang berbeda-beda dihadapan perusahaan.

CRM (Customer Relationship Management) yang merupakan manajemen hubungan pelanggan sangat diperlukan perusahaan dalam melakukan sebuah usaha atau strategi untuk dapat melayani pelanggan dengan baik. Peran CRM di sini tidak terbatas kepada kepuasan pelanggan, tetapi lebih jauh lagi pelanggan dapat terus membeli produk dan atau jasa yang perusahaan tawarkan, sehingga dengan adanya penerapan CRM ini perusahaan dapat melayani pelanggan dengan baik serta tetap mempertahankan loyalitas pelanggan.

Dengan adanya CRM merupakan bukti bahwa pengaruh dalam perkembangan ilmu manajemen yang kini dikategorikan ke dalam ilmu sosial sangat kuat, yang pada awalnya diwarnai oleh pendekatan matematika dan teknik yang kuat. Hingga kini pengaruh pendekatan tersebut semakin kuat, walaupun sumbangan dari bidang ilmu sosial lainnya juga semakin bertambah. Kondisi multi-sources ini menjadikan manajemen sebagai hybrid science menjadi semakin kuat dan semakin menarik banyak orang untuk mempelajari bahkan semakin terasa besar manfaatnya. Kecendrungan kondisi lingkungan ekonomi menjadi hyperkompetitif, peranan ilmu pengetahuan semaking besar untuk keluar dari berbagai masalah atau krisis. 
Serta fenomena bergesernya paradigma ilmu manajemen yang lebih berorientasikepadakamanusiaan(humanistic), dengan semakin dihargainya konsumen, masyarakat luas, serta lingkungan sosial dan lingkungan hidup, menantang dan menekan untuk meredefinisi ilmu manajemen seperti apa yang dapat dikembangkan kemudian. Knowledge-Based Management atau Value-Based Management atau Digital-Based Management atau IT-Based Management menjadi alternatif jawaban untuk masa depan.

\section{DAFTAR PUSTAKA}

Albers, Henry H.,(1969) Principles of Management, A Modern Approach, Wiley and Sons, New York.

Drucker, Peter F., (1954) The Practice of Management, Harper \& Brothers Publishers, New York, 1

Dyche,Jill.(2002).The CRM Handbook. Addison-Wesley,USA.

Fornell,C.,J.D.Michael.,A.W.Eugene,C, Jaesung \& B.E.Barbara, (1996),t he American Customer Satisfaction Index : Nature, Purpose, and Finding, Journal of Marketing,Vol.60,October.

Fayol, Henry,(1949) General and Industrial Management, Sir Isaac Pitman \& Sons. Ltd., London, dalam Albers, Henry H., (1969) Principles of Management, A Modern Approach, Wiley and Sons, New York.

Gulick, Luther,(1969) Notes on the Theory of Organization," dalam Albers, Henry H., Principles of Management, A Modern Approach, Wiley and Sons, New York.

Kalakota, Ravi dan Robinson, Marcia.( 2001 ). E - Business 2.0 Roadmap For Success. Addison - Wesley , USA

O'Brien, James.A.(2005). Introduction To Information System : Essential for The e Business Enterprise, 11th edition. McGraw Hill, New York.

Robb, Russell, Catatan Kuliah Organisasi pada Harvard Business School, (1910) dalam Albers, Henry H.,(1969) Principles of Management, A Modern Approach, Wiley and Sons, New York.

Strene, Jim. (2000). Customer Service on The Internet : Building Relationship, Increasing Loyalty and Staying Competitive, second edition. Wiley Computer Publishing.

Taylor, F.W., (1969) Scientific Management, Harper \& Brothers Publishers, New York, 1947 dalam Albers, Henry H., Principles of Management, A Modern Approach, Wiley and Sons, New York.

Urwick L.,(1943) The Element of Administration, Harper \& Brothers Publishers, New York, dalam Albers, Henry H., (1969) Principles of Management, A Modern Approach, Wiley and Sons, New York. 
Weber, Max (translated by A.M. Henderson and Talcott Parsons),(1947) The Theory of Social and Economic Organizations, Oxford University Press, New York dalam Albers, Henry H., (1969)Principles of Management, A Modern Approach, Wiley and Sons, New York,

Widjaja, A. Tunggal. (2000), Konsep Dasar Customer Relationship Management (CRM). Harvarindo, Jakarta. 